International Journal of Civil Engineering and Technology (IJCIET)

Volume 9, Issue 10, October 2018, pp. 42-49, Article ID: IJCIET_09_10_005

Available online at http://www.iaeme.com/ijciet/issues.asp?JType=IJCIET\&VType=9\&IType $=10$

ISSN Print: 0976-6308 and ISSN Online: 0976-6316

OIAEME Publication

Scopus Indexed

\title{
INNOVATIVE TECHNOLOGY IN INCREASING THE VALUE-ADDED OF THE REMNANTS OF FISHING TRAWLERS IN BAGAN PERCUT VILLAGE, PERCUT SEI TUAN
}

\author{
Ramli \\ Universitas Sumatera Utara, Medan, Indonesia \\ Rusiadi, Nuzuliati, Ade Novalina, Muhammad Isa Indrawan, A.P.U. Siahaan \\ Universitas Pembangunan Panca Budi, Medan, Indonesia
}

\begin{abstract}
The phenomenon of economic inequality between coastal cities and villages is a vital issue for economic development. Breakthrough development strategies need to be sought in order to overcome poverty and equitable development outcomes. Funding sources limit regional economic development, which is carried out by the government in order to realize the planning action is not accommodated in the present. The purpose of this study was to analyze the economic value that was neglected from the remaining catches of Pukat Layang fishers, an inventory of various economic commodities that could be generated from the remaining catch of fisherman flyover and add economic value added and management of the remaining trawler catches which were processed into economic commodities. The method used for primary data collection with observation and experiment techniques. Primary data is obtained directly from official publications. Data analysis used descriptive and comparative techniques before and after treatment. The results of the remaining catch of Pukat Layang fishers have economic market value as an ingredient in the consumption of anchovy, salted fish, as raw material for making fish feed and as jewelry and accessories. Commodity value of economic potential from the remaining catch of Pukat Layang fishermen: anchovy, clamshell, centipede shrimp, small squid, crunchy skin, small fish. Value added to commodities that can be consumed, anchovy, squid, small, and small fish. The added value of small crabs, small fish, and small shrimp/centipede shrimp can be used as the fish meal for feed ingredients.
\end{abstract}

Key words: remaining catches, economic potential commodities, value-added

Cite this Article: Ramli, Rusiadi, Nuzuliati, Ade Novalina, Muhammad Isa Indrawan, A.P.U. Siahaan, Innovative Technology in Increasing the Value-Added of the Remnants of Fishing Trawlers in Bagan Percut Village, Percut Sei Tuan. International Journal of Civil Engineering and Technology, 9(10), 2018, pp. 42-49.

http://www.iaeme.com/IJCIET/issues.asp?JType=IJCIET\&VType=9\&IType $=10$ 
Innovative Technology in Increasing the Value-Added of the Remnants of Fishing Trawlers in Bagan Percut Village, Percut Sei Tuan

\section{INTRODUCTION}

Development is a process of creating better conditions in the present compared to past conditions [1]. North Sumatra Province based on topography has a highland region that produces vegetable production and coastal lowland areas which generally produce fish. The production of these two regions as a center for supplying urban needs, but some residents in this region are still shackled by a circle of poverty that has no origin and some of its territories become pockets of poverty [2]. The fruits of development planning, both before regional autonomy and after regional autonomy have not yet shown the gap between the city and the village in accepting the results of development. Coastal development strategies adopted have not been able to produce better results, among others: the gap between rich and poor is widening, the infrastructure gap between cities and villages, the institutional, economic gap between cities and villages [3]. Gaps in technology access occur between cities and villages. This gap makes the economics of rural areas unable to raise their economies and cut the circle of poverty that does not have a vicious circle of poverty [4].

In Bagan Percut village, fishers tend to catch fish by flying trawlers who go late afternoon and go home tomorrow, and the location of the catch is not far from the coastline. Trawling catches are primarily targeted for catching shrimp, the average length of fishing is 4 hours, and one fishing trip is 4 to 5 times on average. The average catch is about $2 \mathrm{~kg}$ consisting of shrimp, crab, cuttlefish, squid, tonguefish, and octopus. The rest of the catch from the Pukat Layang fishermen needs to be made a Utility of form through an innovative process of technology so that it becomes useful and is a value-added, source of income and makes local revenue Percut Sei Tuan District Percut District Deli Serdang Regency.

The formulation of the problem in this study is: What is the economic value that is neglected from the rest of the catch of the Pukat Layang fishermen. The value of various economic commodities that can be generated from the remaining catches of the fishing Pukat Layang. Economic value added from the management of the remaining trawling catches that are processed into fish meal.

\section{THEORIES}

\subsection{Regional Development Paradigm}

Regional development science is an integration of various theories and applied sciences namely, geography, economics, sociology, mathematics, statistics, political science, regional planning, environmental science and so on. Regional development science is a discipline that is supported by four pillars namely geography, economics, urban planning, and location theory. The development of coastal and marine areas by using an integrated regional development approach at least takes into account six aspects, which are the pillars of regional development, can be seen in the following figure [5].

Regional autonomy is based on Law No. 32/33 of 2004 which gives authority to the regions to regulate their households with the principles of democracy, community participation, equity, and justice and pay attention to the potential and diversity of the region. North Sumatra has a highland and lowland topography that has economic potential of natural resources, artificial culture, and institutions that can be mobilized into the motor of the regional economy. However, this potential has not been mobilized optimally for income generating regions, perhaps due to inadequate supporting infrastructure [6].

Building a sustainable coastal area can minimize structural poverty and cultural impoverishment of the fishing community, through the Agromerin political program, but the efforts of the North Sumatra provincial agromerinpolitan program have not maximally 
boosted the economy of the coastal areas as reflected in the lack of coordination, integrity, and synchronization [7].

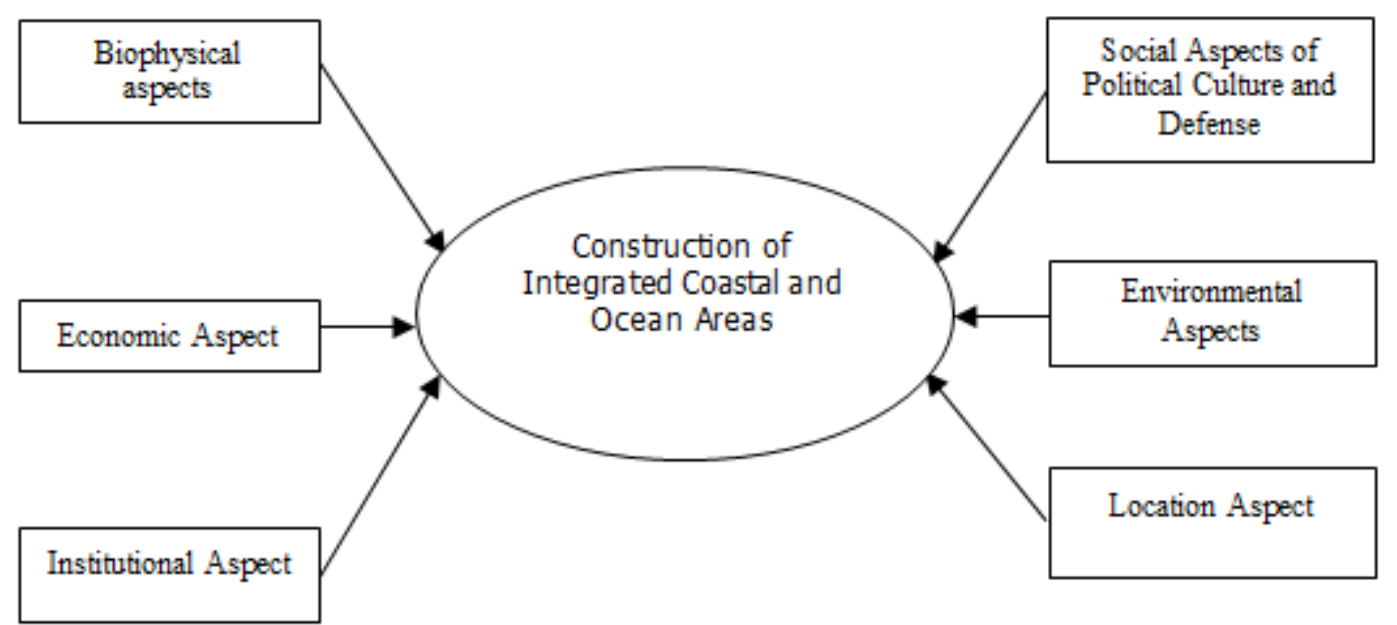

Figure 1 Pillar of Development of Integrated Coastal Areas

In general, in coastal villages, the Percut chart generally depends on life for fish resources that have sea season and time, the existence of connective resources does not guarantee a better life. So they are shackled in a circle of poverty that is not endless. There are many opportunities and opportunities for the family to improve economic capacity based on the regional economic potential, but the constraints are the creative limitations of the business, it is necessary to build motivation for entrepreneurs in the coastal community Chart Percut in Percut Sei Tuan District Deli Serdang District [8].

\subsection{Previous Research}

Preliminary studies that have been carried out include literature studies on the economic development of coastal areas still highlighting the characteristics of fishers with various internal and external. Like the analysis of the coastal area technology transfer model [9].

Fishermen's Poverty Study, a study of economic value added from the catch of fishers to date the literature that has been explored has not been studied. This study will contribute to the theoretical and method and the problem of solving in coastal economic development and increase fishermen's income [10].

Economic development of coastal areas focuses on the multiplication of natural wealth potential efforts to increase the productivity of economic activities of community businesses and efforts to increase the added value of the economic sector of a district/city requires a strategic program that can unite the power of economic potential to carry out a series of economic activities in generating regional economic, creative business [11]-[13].

There are differences in the level of production and income from the tide fishing gear used. The income of fishers in tides is good compared to the income of cantrang fishers, although the level of production is different from that of different fishing gear, as well as the level of income. The level of income is higher than the fishing gear used, but the level of opinion is still low compared to the needs of a decent life [14]. 
Innovative Technology in Increasing the Value-Added of the Remnants of Fishing Trawlers in Bagan Percut Village, Percut Sei Tuan

\section{METHODOLOGY}

\subsection{Research Flow}

PreliResearch location in Bagan Percut Village, Percut Sei Tuan District, Deli Serdang Regency. The action steps for the activity start preparation, data collection, data sorter data presentation from data analysis can be seen in the following chart.

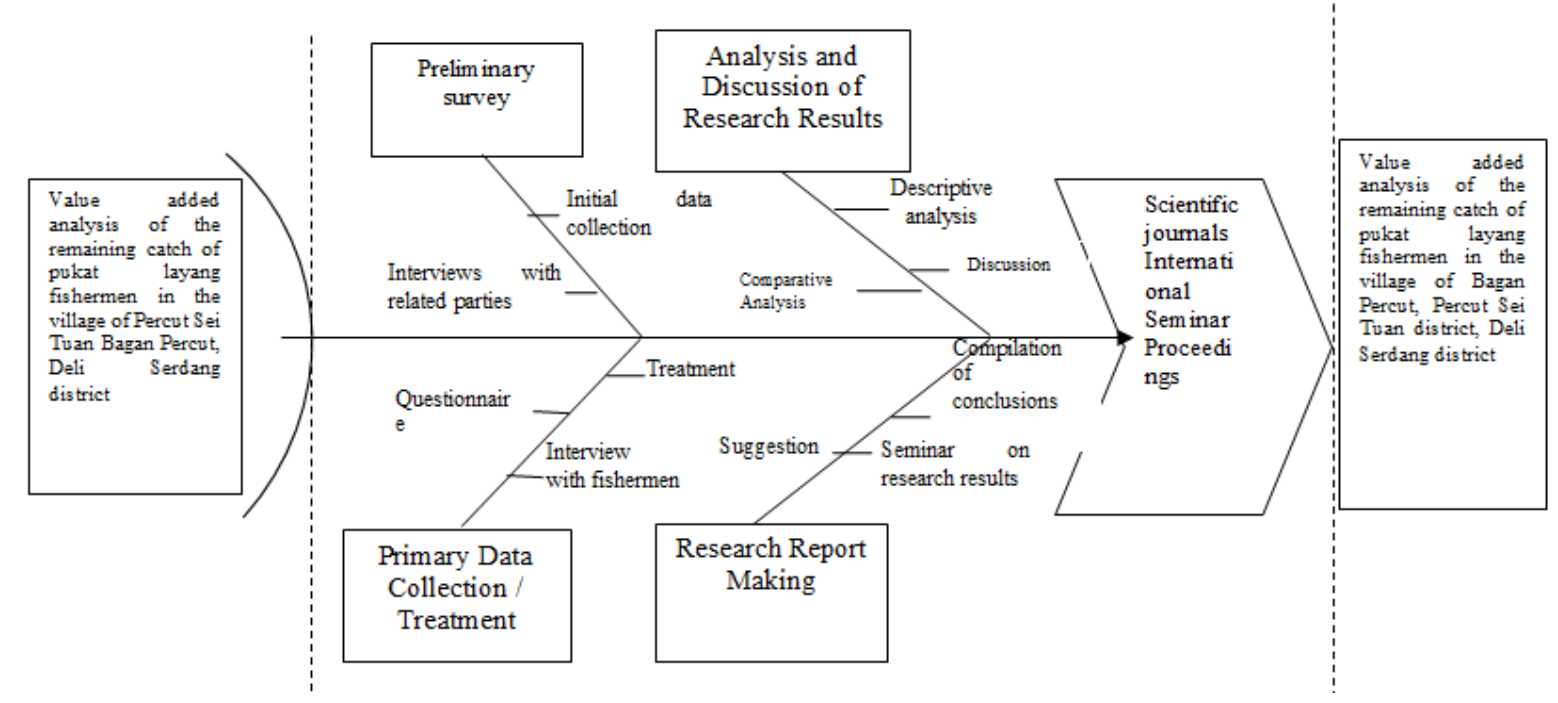

Figure 2 Research Flow Chart

The sampling of the Pukat Layang fishermen used is purposive sampling technique, which is the technique of determining the sample based on the purpose, meaning that fishers who work as fishers meet with enumerators can be sampled. Primary data collection is collected directly from respondents/samples with interview techniques based on the questionnaire that has been given while data from treatment is recorded directly. Secondary data collection is obtained directly from official agencies, such as BPS, Printing in the form of Annual Reports, Books, Journal with direct recording techniques. The sample size used to represent the sample set was 30 people, and the amount of treatment was 50 events [15].

\subsection{Data Analysis}

Similar techniques do the neglected economic value of the remaining catches of fishers after the utility is carried out with the following actions to explain the first problem.

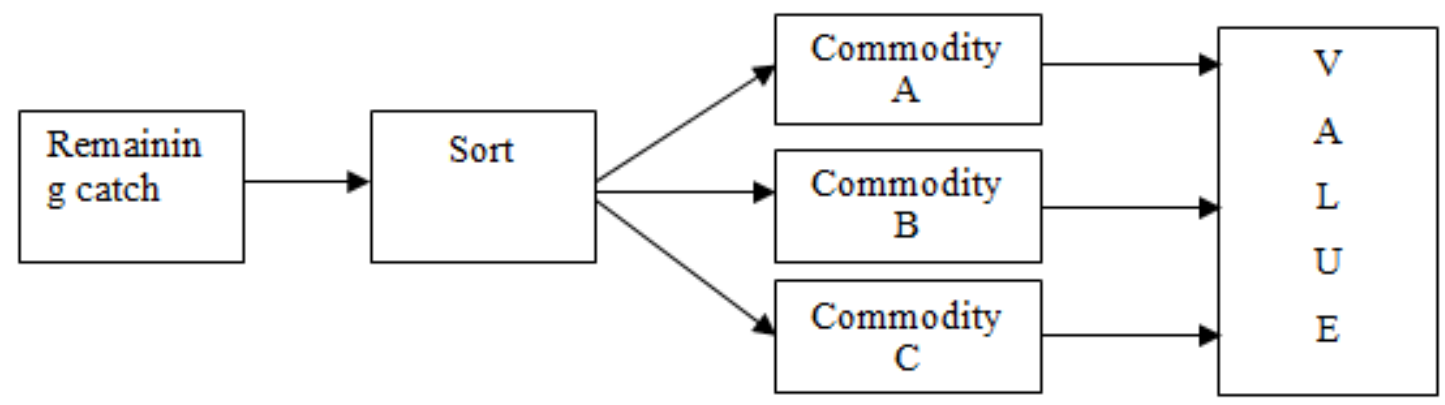

Figure 3 Process for Determining Commodity and Value 


\section{RESULT AND DISCUSSION}

\subsection{Raw Materials for Consumption}

The rest of the fishermen's catches which were thrown back into the sea turned out to have the economic value of the discarded waste, which could be seen as a food ingredient in the form of anchovy, small shrimp, crabs, and small fish. The waste collected from fishers is 32 times and the total weight of wet waste weighing $2,523.25 \mathrm{Kg}$. After sorting the trash or the remaining catch of Pukat Layang fishers, $122.8 \mathrm{~kg}$ of anchovy was obtained. The process of sorting the garbage or the remaining catches of the Pukat Layang fishermen obtained $122.8 \mathrm{~kg}$ of small fish. The process of sorting the waste or the remaining catch of the Pukat Layang fishers was obtained by small shrimp/centipede shrimp as much as $51.9 \mathrm{~kg}$. For small squid $9.1 \mathrm{Kg}$. The results of the sorting of the trash or the remaining catch of the Pukat Layang fishermen were obtained by a small crab $617.9 \mathrm{~kg}$. Seashell skin as much as 104.25. The results of sorting the trash or the remaining catch of the Pukat Layang fishermen were obtained by seashell shells $47.4 \mathrm{Kg}$, and the results of the sorting of the trash or the remaining catches of the trawler were found to be the useless organic waste of $748.8 \mathrm{Kg}$. Depreciation of the remaining catch of Pukat Layang fishers becomes small fish $12.55 \mathrm{Kg}$, anchovy $3.9 \mathrm{Kg}$, small shrimp/centipede $9.8 \mathrm{Kg}$, small squid $0.75 \mathrm{Kg}$, small crab $135.1 \mathrm{Kg}$, clamshells/snail $81.12 \mathrm{~kg}$, shells of shells/crabs $36.6 \mathrm{Kg}$ and organic waste $350.71 \mathrm{Kg}$. In detail can be seen in the following table.

Table 1 Wet Totality and Depreciation of Fishermen's Catching Results

\begin{tabular}{|c|c|c|c|c|c|c|c|c|c|}
\hline & $\begin{array}{c}\text { Number } \\
\text { of Inputs } \\
\quad(\mathrm{Kg})\end{array}$ & $\begin{array}{c}\text { Small } \\
\text { fish } \\
(\mathrm{Kg})\end{array}$ & $\begin{array}{c}\text { Ancho } \\
\text { vy } \\
(\mathbf{K g})\end{array}$ & $\begin{array}{l}\text { Centip } \\
\text { ede } \\
\text { Shrim } \\
\text { p (Kg) }\end{array}$ & $\begin{array}{c}\text { Small } \\
\text { Squid } \\
(\mathbf{K g})\end{array}$ & $\begin{array}{l}\text { Small } \\
\text { Crab } \\
(\mathbf{K g})\end{array}$ & $\begin{array}{c}\text { Shellfish / } \\
\text { Snail } \\
(\text { Kg) }\end{array}$ & $\begin{array}{c}\text { Orna } \\
\text { menta } \\
\text { l } \\
\text { Seash } \\
\text { ells } \\
(\mathrm{Kg}) \\
\end{array}$ & $\begin{array}{c}\text { Organic } \\
\text { Waste }\end{array}$ \\
\hline $\begin{array}{l}\text { Before } \\
\text { drying }\end{array}$ & 2.523 .25 & 122.8 & 23.9 & 51.9 & 9.1 & 617.9 & 104.25 & 47.4 & 748.8 \\
\hline $\begin{array}{l}\text { After } \\
\text { drying }\end{array}$ & 508.53 & 12.55 & 3.9 & 9.8 & 0.75 & 135.1 & 81.12 & 36.6 & 350.71 \\
\hline Price & & 20,000 & 40,000 & 4,000 & 25,000 & $\begin{array}{c}\text { Feed } \\
\text { ingredie } \\
\text { nts }\end{array}$ & $\begin{array}{l}\text { Decoratio } \\
\text { n material }\end{array}$ & $\begin{array}{l}\text { Decor } \\
\text { ation } \\
\text { materi } \\
\text { al }\end{array}$ & - \\
\hline
\end{tabular}

The economic value obtained from each commodity produced for anchovies is Rp. 156,000, - (assuming anchovy market price of Rp. 40,000 per kg). Small fish Rp. 313,750, (assuming a small fish price of Rp. 25,000). Centipede shrimp is worth Rp. 39,200, (assuming the price of small shrimp/centipede is Rp. 4,000). Small squid is worth 18,750, (assumption of a small squid price of Rp. 25,000, - and in detail, the value of each anchovy, small fish and small shrimp commodity can be seen in the following table. 
Innovative Technology in Increasing the Value-Added of the Remnants of Fishing Trawlers in Bagan Percut Village, Percut Sei Tuan

Table 2 Added Value of Anchovy, Minnow and Dry Fish

\begin{tabular}{|c|l|c|c|c|c|c|c|}
\hline No & Commodity & $\begin{array}{c}\text { Wet } \\
\text { Quantity } \\
(\mathbf{k g})\end{array}$ & $\begin{array}{c}\text { Dry } \\
\text { Quantity } \\
(\mathbf{K g})\end{array}$ & $\begin{array}{c}\text { Processing } \\
\text { Costs }\end{array}$ & $\begin{array}{c}\text { Market } \\
\text { Price }\end{array}$ & $\begin{array}{c}\text { Potential } \\
\text { Value }\end{array}$ & $\begin{array}{c}\text { Value- } \\
\text { added }\end{array}$ \\
\hline 1. & Anchovy & 23.90 & 3.90 & 11,950 & 40,000 & 156,000 & 144,050 \\
\hline 2. & Small fish & 122.80 & 12.55 & 61,400 & 25,000 & 313,750 & 252,350 \\
\hline 3. & $\begin{array}{l}\text { Centipede } \\
\text { shrimp }\end{array}$ & 51.90 & 9.80 & 25,950 & 4,000 & 39,200 & 13,250 \\
\hline 4. & Small squid & 9.10 & 0.75 & 20,000 & 25,000 & 18,750 & 1,250 \\
\hline & Total & & & & & & 408,400 \\
\hline
\end{tabular}

Note: The cost of processing 1 bucket $(20 \mathrm{Kg})$ for Rp.10,000, -

The added value obtained from anchovy is Rp. 144,050, - added value obtained from centipede shrimp as much as Rp. 252,350, -, the added value of small fish is Rp. 13,250, - and for the added value of small squid of Rp. 1,250, -. The most of the catches of the floating trawler fishermen are small crabs. This small crab is not edible (according to the fisherman's statement because it is poisonous) and the size of the crab is $4 \mathrm{~cm}$ and is not economically used as food. However, crabs have high potential to be processed into animal feed ingredients, in the form of the fish meal which can be used as the main ingredient in making fish feed. The potential value of small crabs is used as feed flour of Rp. 607,950, - and the added value obtained from feed flour is Rp. 337,750. The potential value of small shrimp used as feed flour is Rp. 52,920. The value-added obtained from feed flour is Rp. 33,320 and small fish the potential value obtained is Rp. 45,180 and this added value is used as the fish meal as much as Rp. 20,080. In detail can be seen in the following table.

Table 3 Added Value of Small Crab, Centipede Shrimp and Small Fish

\begin{tabular}{|l|l|c|c|c|c|c|c|c|}
\hline No & Commodity & $\begin{array}{c}\text { Wet } \\
\text { Quantity } \\
(\mathbf{k g})\end{array}$ & $\begin{array}{c}\text { Dry } \\
\text { Quantity } \\
(\mathbf{k g})\end{array}$ & $\begin{array}{c}\text { Processing } \\
\text { Costs }\end{array}$ & $\begin{array}{c}\text { Quantity } \\
\text { After } \\
\text { Processing }\end{array}$ & $\begin{array}{c}\text { MarketPotential } \\
\text { Price }\end{array}$ & $\begin{array}{c}\text { Value- } \\
\text { Value } \\
\text { added }\end{array}$ \\
\hline & Small crab & 617.9 & 135.1 & 270,200 & 121.59 & 5,000 & 607,950 & 337,750 \\
\hline $\begin{array}{l}\text { Small shrimp } \\
\text { centipede }\end{array}$ & 51.9 & 9.8 & 19,600 & 8.82 & 6,000 & 52,920 & 33,320 \\
\hline & Small fish & 122.8 & 12.55 & 25,100 & 11.295 & 4,000 & 45,180 & 20,080 \\
\hline
\end{tabular}

Note: Process costs per $\mathrm{Kg}=2,000$

Depreciation becomes an average of 1 ounce of $1 \mathrm{~kg}$ of raw material.

\subsection{Raw Materials for Decoration}

The results of the observation of the residual waste captured by Pukat Layang fishermen that have the potential to become decorative products such as curtains, accessories, cigarette ashtrays, tissue boxes. The potential value of waste. Fishing catches can be in the form of thin/decorative shells, shells/snails, and so on.

\subsection{Discussion}

The potential of natural resources that are directed to increase added value is a breakthrough in overcoming the level of poverty in coastal communities. Breakthrough activities must be integrated with other activity programs that are coordinated with rural economic development planning. Village economic development through the action of added value from various types of remnants, the catch of the Pukat Layang fishermen are compiled in a comprehensive 
and coordinated manner. Coastal economic development is very dependent on the preparation of planning for the utilization of natural resources in an area. The preparation of detailed plane planning from the economic development activities of coastal areas from various economic sectors needs to be explained in a regional policy document.

Management of the coastal economy by empowering the capacity of coastal communities in need of working group teams (Pokja) established by the local government, this working group team will develop a plan of action programs to improve the regional economy through various measures to increase added value from various elements of the remaining catch of fishers. The action program that is developed needs to get input from various government and stakeholders. This action program document is the basis for the action of the working group, government, and stakeholders. This action program document is the basis for the action of the working group team, government and stakeholders and this management is autonomous for the working group team or all the costs needed for operational activities are financed by the government and other non-binding sources.

\section{CONCLUSIONS}

The rest of the catch from the Pukat Layang fishermen has added value to economic potential as raw material and consumption material. The rest of the catch from the Pukat Layang fishermen contains various economic potential values: anchovy, small mussels, large mussels, centipede shrimp, bark bark, small crabs. Value-added from anchovy Rp. 144,050, small fish Rp. 252,350, centipede shrimp Rp. 13,250, and small squid Rp. 1,250. From the results of small crab processing, centipede shrimp and small fish are made into fish meal, giving added value: for small crabs Rp. 337,750, small shrimp / centipede Rp. 33,320, - and small fish Rp. 20,080, - The added value of the crust, small shells, and large shells have not been added value treatment. The raw material for centipede shrimp and small pellets has not been added value treatment as the production of raw material fish feed.

\section{REFERENCES}

[1] Rusiadi, Ramli, D. Ruslan, dan R. Ginting, "Monetary Transmission Of State Emerging Markets Line Asset Prices: Inflation Control Leading Indicators," Int. J. Civ. Eng. Technol., vol. 9, no. 7, hal. 698-707, 2018.

[2] Rusiadi dan A. Novalina, "Monetary Policy Transmission: Does Maintain the Price and Poverty Stability is Effective?," Jejak J. Ekon. dan Kebijak., vol. 11, no. 102, hal. 78-82, 2018.

[3] A. S. Wenger et al., "Management strategies to minimize the dredging impacts of coastal development on fish and fisheries," Conserv. Lett., hal. e12572, Jun 2018.

[4] D. J. McCarthy dan D. M. Thomas, "International and National Principles and Area Based Local Application for Sustainable Coastal Development," J. Coast. Zo. Manag., vol. 20, no. 2, 2017.

[5] Budiharsono, Pengelolaan Sumber Daya Pesisir Dalam Pembangunan Ekonomi Wilayah Pesisir. 2005.

[6] Ramli, Kondisi Dan Harapan Infrastruktur Pembangunan Ekonomi Daerah Sumatera Utara Dalam Menghadapi Pasar Tunggal Tahun 2015. Persentase Masterplan Kek Seimangke, 2015. 
Innovative Technology in Increasing the Value-Added of the Remnants of Fishing Trawlers in Bagan Percut Village, Percut Sei Tuan

[7] Ramli, "Perspektif Kesiapan Infrastruktur Dan Tata Ruang Dari Kawasan Ekonomi Khusus (Kek) Sei Mangkei Sumatera Utara," in Seminar Nasional, 2012.

[8] Ramli, Proposal: Percepatan Pengembangan Agroindustri Rumah Tangga Nelayan Yang Berbasis Limbah Kepiting Dan Ikan Nila Di Desa Bagan Percut Kecamatan Percut Sei Tuan Kabupaten Deli Serdang. 2016.

[9] Tajerin, "Peranan Teknologi Dalam Konvergensi Pertumbuhan Ekonomi Antar Daerah Pesisir di Kawasan Timur Indonesia," J. Ekon. Pembang., vol. 2, no. 3, 2007.

[10] Nurlina, Disertasi: Analisis Kemiskinan Nelayan di Pesisir Aceh Bagian Timur. Medan: Fakultas Ekonomi dan Bisnis Universitas Sumatera Utara, 2016.

[11] S. Suroso et al., "Autoregression Vector Prediction on Banking Stock Return using CAPM Model Approach and Multi-Factor APT," Int. J. Civ. Eng. Technol., vol. 9, no. 9, hal. 1093-1103, 2018.

[12] W. S. Purba et al., "Relationships Among Knowledge, Attitude and Behavioral Intention of Waste Management Technology," Int. J. Civ. Eng. Technol., vol. 9, no. 9, hal. 792-798, 2018.

[13] A. I. F. Lubis et al., "Strategy for Improving Science and Welfare Through Community Empowerment Technology," Int. J. Civ. Eng. Technol., vol. 9, no. 9, hal. 1036-1046, 2018.

[14] Purwasih, Analisis Perbandingan Pebndapatan Nelayan Pukat Cincin (Pure Seine) dan Pancing Tonda (troll line) di PPP Tamperan Pacitan, Jawa Timur. Pacitan, Jawa Timur: Fisheries Resources Utilization Management and Technology, 2016.

[15] Sugiyono, Metode Penelitian Kuantitatif dan Kualitatif $R$ dan D. Bandung: Alfabeta, 2009. 